\title{
Comparative Ultrastructural Study of Normal and Grafted Skin in the Frog, Rana pipiens, with Special Reference to Neuroepithelial Connections
}

\author{
P. H. J. Nafstad \\ Department of Anatomy, The Veterinary College of Norway, Oslo, Norway \\ R. E. Baker \\ Department of Zoology, The University of Michigan, Ann Arbor, Michigan, U.S.A. \\ Received February 15, 1973
}

\begin{abstract}
Summary. Recent investigations have suggested specific differences in back and belly skin in anurans which appear to influence the quality of reflex responses obtained from various areas of the animals body. The present investigation represents a comparative morphological study of back and belly skin in control and skin-grafted Rana pipiens, with special regard to the neuroepithelial relationships. A distinct difference in pigmentation of back and belly skin was observed. Intra-epithelial Merkel cells were present in all skin samples studied. The origins of the numerous unclassifiable cells in the Merkel cell region are discussed in relation to a presumed coordinating function of the Merkel cell during epithelial differentiation. Epitheliomesenchymal interactions were observed in the richly innvervated dermal regions. Two types of morphologically different intra-epithelial nerve endings were observed. These observations are discussed in relation to earlier observations on vertebrate skin and in relation to misdireeted. reflex responses obtained in skin-grafted anurans.
\end{abstract}

Key words: Skin - Anurans - Regional differences in grafts - Neuroepithelial relationships - Light and electron microscopy.

\section{Introduction}

Recent investigations have indicated anuran skin might play a central role in the formation of cutaneous nerve reflex ares and/or their function in the developing animal (Miner, 1956; Baker and Jacobson, 1970; Baker, 1972). Misdirected reflex responses were obtained in Rana pipiens and Bufo vulgaris when pieces of back. and belly skin were interchanged at specific stages of development. It was adumbrated that these misdirected reflexes might depend on differences in cutaneous receptor organ formation and/or morphological organization of back and belly skin.

Merkel (1880) described the presence of receptor cells (Merkel cells) in back skin of the frog, but failed to observe them in belly skin. It has been proposed that epithelial cells might play a role in the formation of dermal Merkel cells (Munger, 1965; Lyne and Hollies, 1971; Nafstad, 1971 a, b; Nafstad, 1972). Regional specificities in the epithelia might therefore influence the morphology of receptor organs and secondarily qualitatively influence information of locality to local cutaneous nerves.

Hay (1960) studied the epithelial innervation in regenerating amphibian limbs by electron microscopy, but did not describe Merkel cells or other receptor organs. 
An ultrastructural study on back and belly skin in Rana pipiens and Rana catesbeiana was carried out by Farquhar and Palade (1965). In that study the authors gave a relatively detailed morphological description of the epidermal cell types, but did not mention intra-epithelial nerves or Merkel cells.

A comparative ultrastructural study focused on general differences in frog back and belly skin and their neuroepithelial relationships appeared necessary. It was anticipated such an investigation might provide evidence of a morphological basis for the misdirected reflexes obtained in the physiological experiments mentioned above. Samples of back and belly skin from control and skin-grafted Rana pipiens were examined in the present investigation. Convincing qualitative differences in cutaneous nerve and receptor organ morphology in all skin types were not documented by the present findings. A description of the neuroepithelial relationships in back and belly skin will be given in this paper and are discussed in relation to the misdirected reflex responses characteristic to skin-grafted Rana pipiens.

\section{Materials and Methods}

Tadpoles of Rana pipiens were selected for operation at early larval stages (VIII-XII, Taylor and Kollros, 1946). A single patch of skin, extending from the dorsal midline to ventral midline on one side of the animals abdomen was excised, rotated through 180 degress and returned to the wound. Following the appearance of misdirected reflex responses in the skingrafted, post-metamorphic juveniles, 5 sibling control and 5 skin-grafted animals were selected for this study. The animals were deeply anesthetized with sodium pentobarbital and immersed in a $2 \% \mathrm{OsO}_{4}$ solution (Millonig) or in a $1 \% \mathrm{OsO}_{4}$ solution (Palade). The time for fixation varied between 4 and 14 hours.

Samples of black skin spots, non-spotted back skin, belly skin and grafted back and belly skin were dissected free, prepared in small blocks, dehydrated in an acetone series and embedded in Araldite. Single and serial sections were doubly-stained by aqueous uranyl acetate and lead citrate, or by lead citrate alone. Light microscopy was carried out on 1-2 u thick toluidine blue-stained sections.

\section{Results}

Comparative Observations of Back and Belly Skin. Macroscopically Back skin in Rana pipiens showed a moderate degree of pigmentation with heavy pigmented spots scattered throughout the dorsal and lateral surfaces. One distinct subepithelial pigment cell layer was revealed by light microscopy (Fig. 1). In the dark pigment spots, this layer was formed by the "dermal chromatophore unit" as described by Bagnara, Taylor and Hadley (1968), consisting of units of three different pigment cell types (xantophores, iridophores and melanophores). In the moderately pigmented parts of the back skin, however, one or two of the pigmented cell types were commonly lacking. The darkness of the spot also seemed to depend on the presence of intra-epithelial cell melanosomes (Fig. 2).

Vertically arranged cells could be observed interrupting the pigment cell layer throughout back skin sections. When this was observed, the epithelium was commonly indented with a reduced number of cell layers (Figs. 1 and 14).

In the light belly skin intra-epithelial melanocytes, sub-epithelial xantophores and melanophores were only occasionally present. The dominating pigment cell of belly skin was the iridophore (Fig. 11). These cells were organized in two distinct 
layers; one proximal iridophore layer closely attached to the epithelium, and one distal iridophore layer situated in the region below the moderately developed epithelial glands (Figs. 3 and 4). The vertically arranged sub-epithelial cells described in back skin were also present in belly skin, but apparently in reduced numbers.

Comparative Observations of Grafted Back and Belly Skin. The back and belly skin examined from the skin transplants did not differ significantly from the back and belly skin of the control animals (Figs. 6 and 7).

Neuroepithelial Observations. According to earlier electron microscopy investigations, cutaneous nerves are covered by supporting cell cytoplasm at the site of the epithelial entrance (Hay, 1960; Munger, 1965; Andres, 1966; Nafstad, 1972). Cutaneous nerve profiles were easily distinguished from other intra-epithelial cytoplasmic profiles by their characteristic slender and dense mitochondria (Hay, 1960; Fig. 11). By far the most common intra-epithelial nerve type consisted of long and beaded fibers which ran proximal to the basal cells of the epidermis, primarily parallel with the epithelial surfaces. The axoplasmic expansions of these cutaneous nerve fibers were rich in glycogen-like granules (Figs. 8 and 11). Morphologically these nerves appeared to correspond to the intra-epithelial nerves described by Hay (1960) in the epithelial cap of regenerating salamander limbs. The regular attachment between these types of nerves and the Merkel cells (Figs. 8 and 11) indicate they may represent the tactile-sensitive fibers of the frog epithelium.

Occasionally a second type of cutaneous nerve fiber was observed predominantly distal in the epithelium, but also sub-epithelially. The endings of these latter nerve fibers were characterized by numerous dense-core granules (diameter of about $1200 \AA$ ), clear vesicles (diameter of about $700 \AA$ ) and mitochondria (Fig. 10). Based on the morphology of these cutaneous neural elements, there was a resemblance to neural elements proported to represent monoamine-containing nerve endings (Høkfelt, 1968; Nakai, 1971).

On one occasion it was possible by means of serial sections to follow a bundle of nerve fibers from the sub-epithelial region to their blind intra-epithelial endings (Figs. 9 and 10). Morphologically these cutaneous nerves differed from those described in earlier literature in that at the site of epithelial entrance they are free of supporting cell cytoplasm (Fig. 9). Their intra-epithelial penetrations were relatively short (approximately $25 \mu$ ) compared to the "tactile-sensitive" nerves. One fiber showed a large terminal expansion with axoplasmic similarities to the terminal expansions of the tactile-sensitive nerve endings described in mammals and birds (Andres, 1966; Andersen and Nafstad, 1968; Fig. 10). The remaining fibers in the nerve bundle form bouton-like expansions close to the stalk of the assumed "tactile-sensitive" nerve (Fig. 10). The bouton-like expansions correspond morphologically to the "monoamine" nerves described above. Contrary to the relative ease of tracing "tactile-sensitive" nerve endings from epithelial nerve fibers, it was difficult, even in serial sections, to observe convincing continuities between the "monoamine" nerve expansions and their nerve trunks. These same experiences were encountered during a study of similar nerve endings in the Herbst corpuscle (Nafstad and Andersen, 1970). It cannot be excluded that these nerve endings undergo a budding-off process and thus represent a form of neurosecretion. 

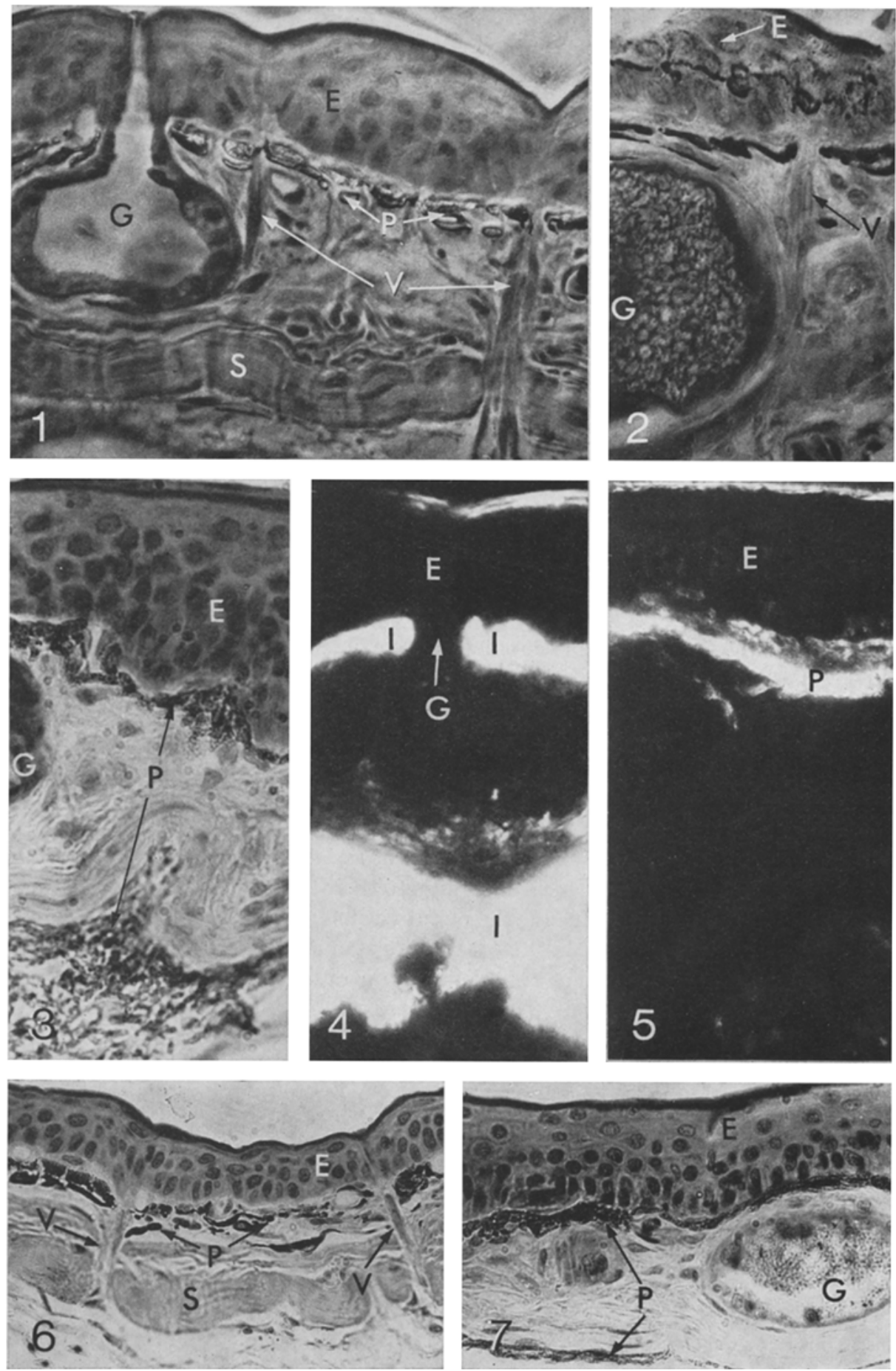

Figs. 1-7 
Intra-epithelial Merkel cells were present in both control back and belly skin as well as skin grafts studied (Fig. 11). Roughly calculated, about $0.3 \%$ of the epithelial cells were found to be of the Merkel cell type, and in serial sections they were always observed in contact with expansions of beaded nerves already described (Figs. 8 and 11). Merkel cells in anurans appear to be morphologically identical to Merkel cells in mammals and birds. Even the tendency of finger-like protrusions which make contact with neighboring epithelial cell nuclei were present (Nafstad, $1971 \mathrm{~b}$; Fig. 12).

It was a general impression that the epithelial cell "population" surrounding the Merkel cells possessed heterogeneous cytological characteristics (Fig. 11). Epithelial cell mitoses were numerous in the regions, with a quantitative reduction in epithelial desmosomes taking place during cell division (Figs. 11 and 13). This phenomenon was most prominent in the basal cell layer. Further, paired mesenchymal cells, one intimately apposed to the other, were common findings in the basal cell layer (Fig. 13). Sub-epithelial cell profiles were frequently connected with the epithelial cells by vesicular or fibrillar cytoplasmic bridges. The epitheliomesenchymal connections which break the continuity of the epithelial basal lamina

Fig. 1. Moderately pigmented back skin. Note the decrease of epithelial thickness in regions where sub-epithelial vertically arranged cells $(V)$ are present. Similar sub-epithelial cell groups were supposed by Merkel to represent receptor cells because of their association with nerve endings. In the electron microscope, however, the cells did not show the cytoplasmic characteristics of receptor cells (see Fig. 15). $E$ epithelium, $G$ epithelial gland, $P$ pigment cell layer, $S$ solid collagen layer. $\times \mathbf{3 8 0}$

Fig. 2. Heavily pigmented back skin (dark spot). The increased pigmentation is seen in the occurrence of epithelial cell melanosomes $(E)$, intra-epithelial melanocytes and, as revealed by electron microscopy, relatively complete chromatophore units present (Bagnara et al., 1968) in the single sub-epithelial pigment cell layer. $E$ epithelial cell melanosomes, $V$ vertically arranged sub-epithelial cells, $G$ epithelial gland. $\times 380$

Fig. 3. Belly skin. The main difference between the back and the belly skin is the presence of two distinct iridophore cell layers $(P)$ in the latter. Convincing intra-epithelial "Merkel cells" which were overlooked by Merkel in 1880 , were difficult to demonstrate in the belly as well as in back skin by light microscopy. $E$ epithelium, $G$ epithelial gland. $\times \mathbf{3 8 0}$

Fig. 4. Belly skin. In dark-ground illumination the empty platelets of the iridophores (see Fig. 11) are intensely reflective to light. $E$ epithelium, $G$ epithelial gland duct, $I$ iridophore cell layers. $\times 380$

Fig. 5. Dark-ground illumination of back skin. Note the absence of a distal iridophore cell layer and the relative reduced light reflection of the proximal pigment cell layer as compared. to belly skin (see Fig. 4). The richness of iridophores together with the paucity of melanophores and xanthophores in belly skin indicate a marked quantita tive difference of metabolism in the two skin types. $E$ epithelium, $P$ proximal pigment cell layer. $\times 380$

Figs. 6 and 7. The grafted back skin (Fig. 6) and the grafted belly skin (Fig. 7) did not reveal morphological differences compared to the control material neither in the light microscope (Figs.) nor in the electron microscope. $E$ epithelium, $G$ epithelial gland, $P$ pigment cell layer, $S$ solide collagen layer, $V$ vertically arranged subepithelial cells. $\times 252$ 

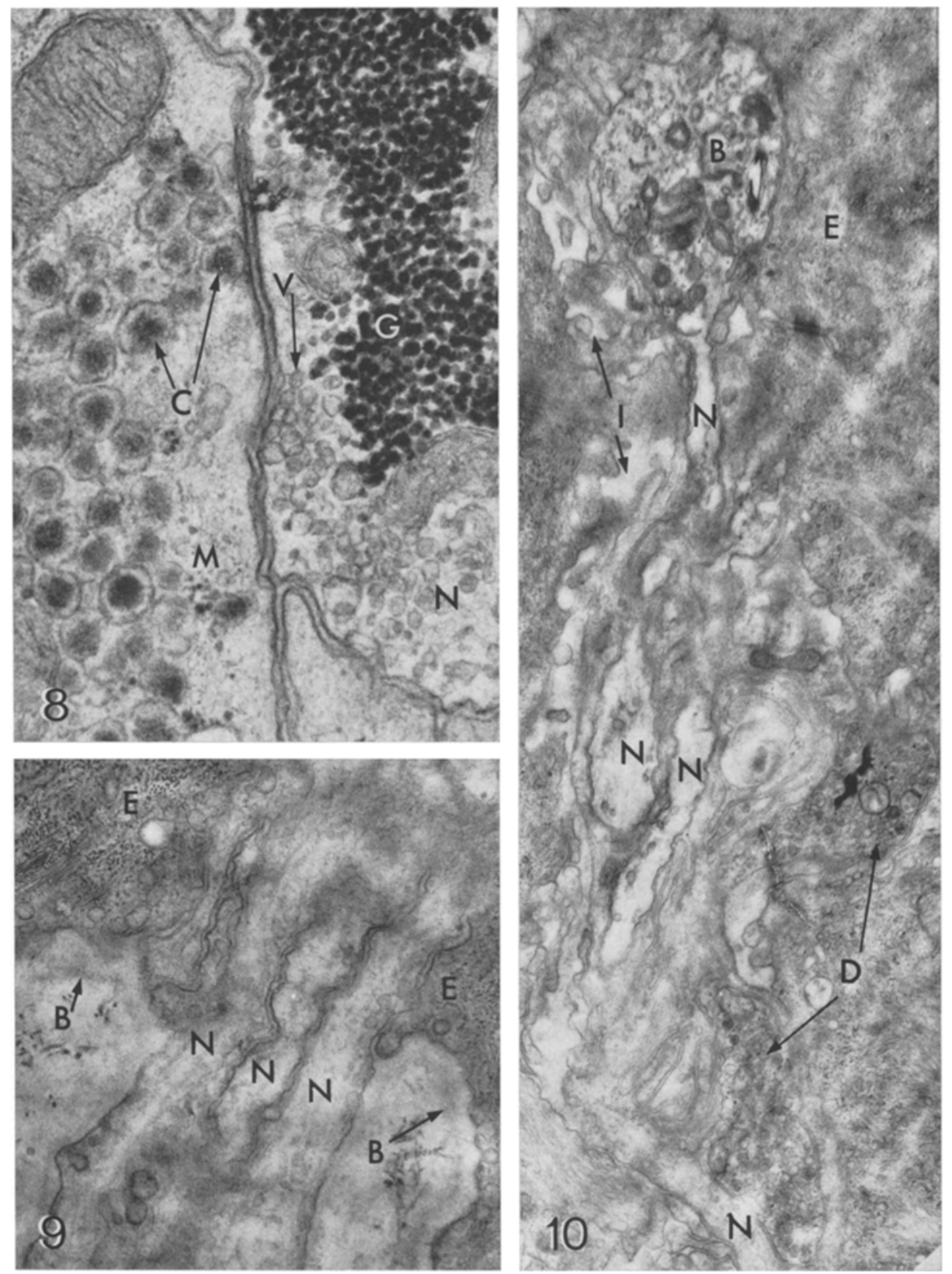

Fig. 8. The junction between the Merkel cell $(M)$ and a "tactile-sensitive" nerve expansion $(N)$. Aggregations of Merkel cell granules $(C)$ and clear nerve vesicles $(V)$ are present. According to earlier reports, the cytomembranes show increased electron density in the regions of Merkel granules aggregations. The opposite impression is gained when aggregations of clear nerve vesicles are present. This phenomenon may be interpreted as either two different steps in a "cell-to-nerve transmission" or as a reflection of a "two-way transmission" between the Merkel cell and the nerve. $\times 45000$ 
showed more or less indistinct cytomembranes (Figs. 16 and 17). Sub-epithelial nerve profiles were common findings in the region of epithelio-mesenchymal contacts; especially in dark spot epithelium (Fig. 15).

\section{Discussion}

The relationship between structure and function of receptor organs and dermal nerve endings has heretofore been difficult to understand, mainly because of the variable morphology in these structures. Oppenheimer, Palmer and Weddell (1958) regarded the morphological variations of the nerve end organs in mammalian conjunctiva as a reflection of nerve growth and decay. This view was supported by Fitzgerald (1962) who studied bulbous corpuscles in pig epidermis. Recent ultrastructural studies confirm that the morphology of the dermal mechanoreceptors may represent different steps in a "turn-over" of the receptor organs rather than static anatomical constructions (Nafstad, 1971 b, 1972). The numerous intraepithelial nerves which could be observed in the transplanted skin samples in this study were further documentation of the mobility of the dermal nerve endings.

It should be expected, if the considerations presented above are correct, that the different steps in the epithelial in-growth of the nerve endings would be reflected morphologically. The serial sectioned trunk of nerve endings (Fig. 10) might represent nerves in the initial phase of epithelial infiltration. The fact that these fibers were found free of Schwann cell cytoplasm at the site of the epithelial entrance indicated that the epithelial contact might just have been established (Fig. 9). In an earlier paper it was presumed that the penetrating nerve endings in the sub-epithelial region temporarily might be free of "supporting cell cytoplasm" (Nafstad, 1972). The absence of glycogen in the most proximal cutaneous nerve endings may be a result of high energy consumption at the growing end of the fiber (Fig. 10). The mixed quality of the nerves in the trunk may further indicate that an interaction takes place between qualitatively different nerves on their way into the epithelium.

The intra-epithelial Merkel cells observed in the amphibian epithelium show a surprising ultrastructural similarity with the Merkel cells of mammals and bird (Munger, 1965; Andres, 1966; Andersen and Nafstad, 1968). It is somewhat confusing, however, that Merkel (1880) described the receptor cells of amphibian skin

Fig. 9. Epithelial entrance of a serial sectioned nerve trunk. Note the absence of supporting cell cytoplasm (Schwann cells) in the nerve trunk. $B$ epithelial basal lamina, $E$ epithelial cells, $N$ nerve fibers. $\times 27000$

Fig. 10. Proximal endings of nerve fibers (see Fig. 9) about $25 \mu$ into the epithelium. Two different types of nerve endings are seen in the inter-cellular region. The bulbous expanded nerve ending $(B)$ represents the most proximal end of the trunk and shows similarities with tactile-sensitive nerve endings in other vertebrates. It was difficult to demonstrate convincing continuities between the end bulbs $(D)$ which contain numerous dense-core vesicles and the nerve fibers in serial section. This may indicate that such bulbs are budded off, and represent a form of neurosecretion. $E$ epithelial desmosomes, $I$ intercellular space, $N$ nerve fibers. 

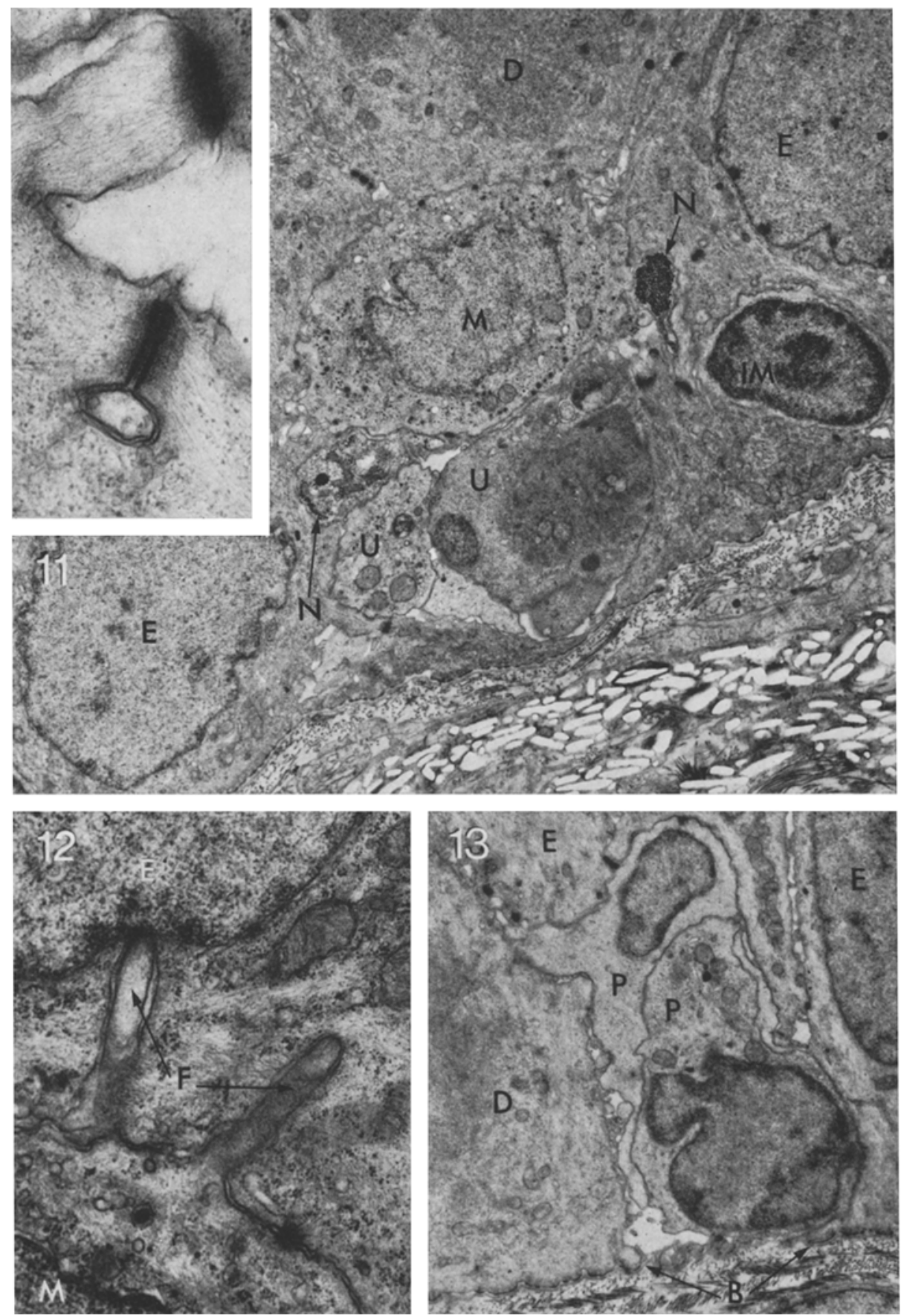

Figs. $11-13$ 
to be located sub-epithelially and not intra-epithelially. On the other hand, the sub-epithelial cells which Merkel somewhat doubtfully described as receptor cells were not found to have ultrastructural characteristics of the Merkel cells in this study. Merkel classified the sub-epithelial cell groups as receptor cells because of their close association with branching cutaneous nerve endings which have been verified by the electron microscope (Fig. 15).

It has earlier been proposed (Nafstad, 1971 b, 1972) that Merkel cells, besides being involved in the function of mechanoreception, might possibly have a coordinating function in dermal differentiation. The increased mitotic activity and the numerous unclassifiable cell profiles in the vicinity of Merkel cells support this view (Fig. 11). According to different authors (for review see Campbell and Campbell, 1968), desmosomes may or may not remain intact during cell division. This impression was also gained in the present study. In the basal cell layer, the dividing cells frequently displayed intra-cytoplasmic desmosomes, which indicated a withdrawal of desmosomes during some cases of mitosis (Fig. 11, inset). The slightly triangular vacuoles associated with the intra-cytoplasmic desmosomes have been experimentally shown to be characteristic of desmosomal autophagocytosis (Overton, 1968). Therefore, it can not be excluded that the paired "mesenchymal cells" commonly observed in the proximity of Merkel cells represent recently divided and transformed basal cells (Fig. 13).

The epithelio-mesenchymal connections (Figs. 16 and 17) observed in this amphibian skin study generally resemble those of the richly innervated mammalian skin described in a previous paper (Nafstad, 1971 b). Although it can not be excluded that this represents an invasion of mesenchymal cells into the epithelium, several observations suggest a migration of epithelial cells:

a) the thin and empty epithelium which can often be seen when the epitheliomesenchymal connections are present (Figs. 1 and 14);

b) the cytoplasmic similarities between the epithelial cells and the vertically arranged sub-epithelial cells (Fig. 15);

Fig. 11. A heterogeneous cytomorphology combined with a high mitotic activity is commonly observed in the regions of intra-epithelial nerves and Merkel cells. Note the significant differences between the nerve mitochondria and those of the other cytoplasmic profiles. $D$ dividing epithelial cells, $E$ epithelial cells, $I$ sub-epithelial iridophore, $I M$ immature intraepithelial "mesenchymal cell", $M$ Merkel cell, $N$ nerve expansions, $U$ unclassifiable cell profiles. $\times 5750$. Inset: Desmosomal autophagocytosis in a mitotic basal cell. $\times 30000$

Fig. 12. According to earlier observations in mammalian epithelia, the finger-like Merkel cell protrusions make contact with neighboring epithelial cell nuclei. The functional significance of this phenomenon is unknown, but such contacts may be a morphological reflection of a coordinating function of the Merkel cells in epithelial cell differentiation. $E$ epithelial cell nucleus, $F$ finger-like protrusions, $M$ Merkel cell nucleus. $\times 20000$

Fig. 13. Intimately apposed, paired "mesenchymal" cells are frequently present in the basal cell layer. Because of the desmosomal autophagocytosis of some of the dividing basal cells (see Fig. 11 inset) it cannot be excluded that they are of epithelial cell origin. $B$ epithelial basal

lamina, $D$ dividing basal cell, $E$ epithelial cells, $P$ paired "mesenchymal "cells. $\times 4600$ 

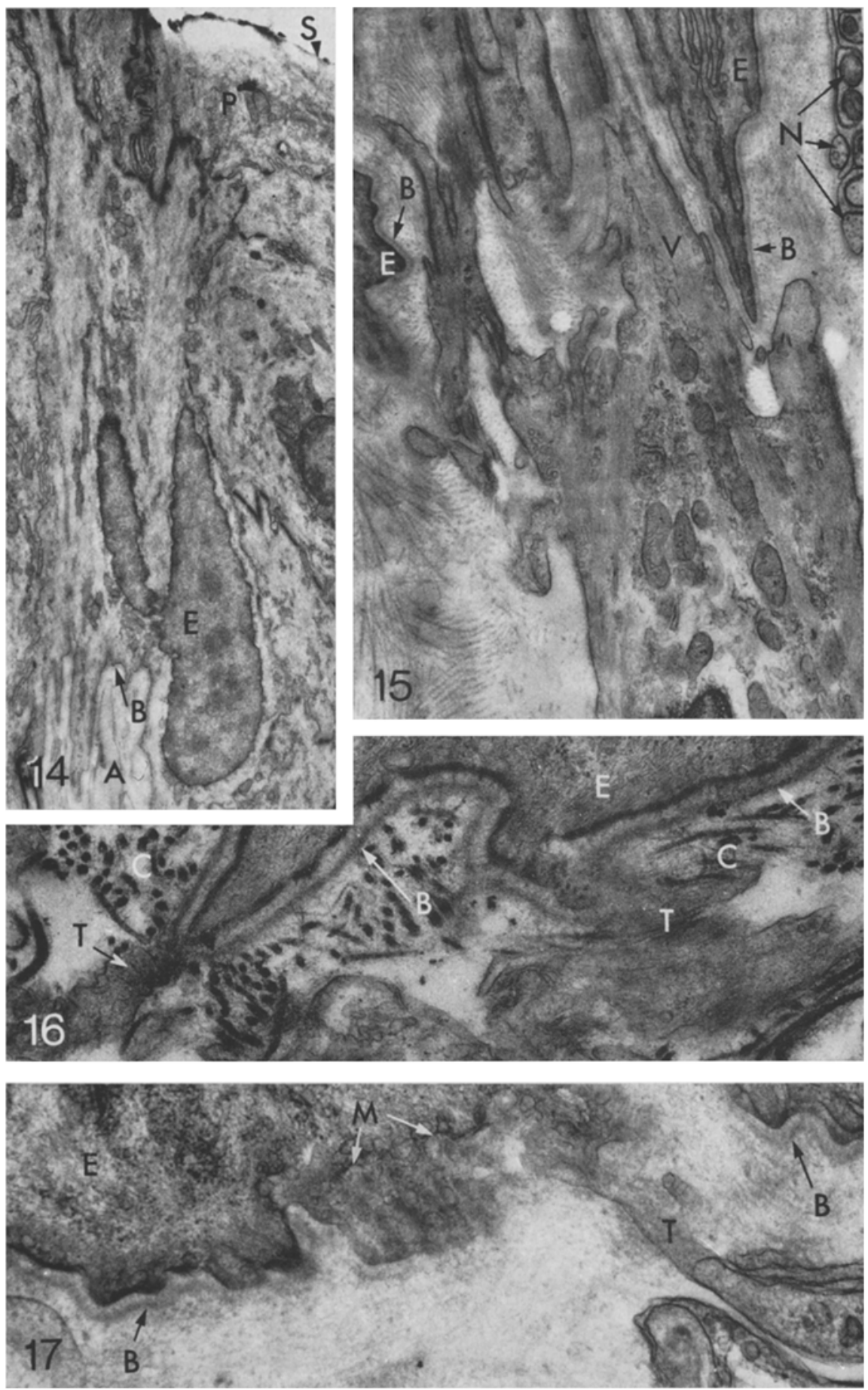

Figs. $14-17$ 
c) the tendency of the basal cells to organize new cytomembranes above exfoliated, excessive cytoplasmic sheets (Fig. 17);

d) recent investigations which show that epithelial cells lose their basal lamina when they protrude into the sub-epithelial environment (Toner and Ferguson, 1971 ; Nafstad, $1971 \mathrm{~b}$; Mathan, Hermos and Trier, 1972).

In earlier studies of mammalian tissues the epithelial cells were proposed to participate in the formation of sub-epithelial bulbous corpuscles. In the amphibian skin where bulbous corpuscles are absent (Merkel, 1880), the functional task of an epithelial cell migration may be difficult to understand. The epithelial cells might, however, participate in the substitution of sub-epithelial nerve-supporting cells (Schwann cells); a substitution which should be expected to be necessary if a growth and decay of peripheral nerve endings takes place.

The present study suggests peripheral cutaneous nerve morphology in grafted skin of Rana pipiens does not undergo a structural change which could account for the development of misdirected reflex responses in the post-metamorphic juvenile. No significant changes between control and grafted skin morphology or nerve endings was apparent. These findings do not vitiate, however, the possibility of an informational transfer, followed by centripetal flow, between cutaneous nerve endings and skin with a corresponding central response along lines already hypothesized (Jacobson and Baker, 1969). These data taken in conjunction with earlier evidence regarding the lack of selective regrowth of severed cutaneous nerve fibers (Baker, 1972) continue to suggest that a centrally occuring phenomenon in response to skin rotations is associated with the development of behavioral reflex responses.

Fig. 14. The thickness of the epithelium may be extremely reduced in the regions where vertically arranged sub-epithelial cells are present (see Fig. I). In this figure the epithelium is reduced to only one complete epithelial cell $(E)$ covered by the nucleus-free semi-cornified cell plate $(P)$. $A$ autolytic cytoplasmic profile, $B$ epithelial basal lamina, $S$ epithelial surface.

$$
\times 4600
$$

Fig. 15. Vertically arranged sub-epithelial cell showing cytoplasmic similarities with epithelial cell. When vertically arranged cells are observed closely attached to the epithelium, the only eytoplasmic difference between epithelial and sub-epithelial cells is the absence of an epithelial basal lamina and desmosomes in the latter. Note the nerve profiles $(N)$ which usually are seen close to the vertically arranged sub-epithelial cells. $B$ epithelial basal lamina, $E$ epithelial cells $\times 14000$

Fig. 16. Epithelio-mesenchymal cytoplasmic bridges usually possess indistinct cytomembranes and a more or less fibrillar cytoplasm. These bridges are interpreted to represent excessive cytoplasm which is transformed to collagen and intercellular matrix. $B$ epithelial basal lamina, $C$ collagen fibers, $E$ epithelial cell, $T$ transforming cytoplasmic bridges. $\times 30000$

Fig. 17. Cytoplasmic transformation (see Fig. 16) and the reconstruction of the epithelial cell cytomembranes appear to be processes which are synchronized in time. $B$ epithelial basal lamina, $E$ epithelial cell, $M$ "membrane reconstruction", $T$ transforming epithelio-mesenchymal bridges. $\times 30000$ 


\section{References}

Andersen, A. E., Nafstad, P. H. J.: An electron microscopic investigation of the sensory organs in the hard palate region of the hen (Gallus domesticus). Z. Zellforsch. 91, 391-401 (1968).

Andres, K. H.: Über die Feinstruktur der Rezeptoren an Sinushaaren. Z. Zellforsch. 75, $339-365(1966)$.

Bagnara, J. T., Taylor, J. D., Hadley, M. E.: The dermal chromatophore unit. J. Cell Biol. 38, 67-79 (1968).

Baker, R. E.: Biochemical specification versus specific regrowth in the innervation of skin grafts in Anurans. Nature (Lond.) 236, 235-237 (1972).

Baker, R. E., Jacobson, M.: Development of reflexes from skin grafts in Rana pipiens: Influence of size and position of grafts. Develop. Biol. 22, 476-494 (1970).

Campbell, R. D., Campbell, J. H.: Origin and continuity of desmosomes. Origin and continuity of cell organelles, p. 261-298. Berlin-Heidelberg-New York: Springer 1971.

Farquhar, M. G., Palade, G. E.: Cell junctions in amphibian skin. J. Cell Biol. 26, 263-291(1965).

Fitzgerald, M. J. T.: On the structure and life history of bulbous corpuscles (Corpuscula nervorum terminalia bulboidea). J. Anat. (Lond.) 96, 189-208 (1962).

Hay, E. D.: The fine structure of nerves in the epidermis of regenerating salamander limbs. Exp. Cell Res. 19, 299-317 (1960).

Hökfelt, T.: In vitro studies on central and peripheral monoamine neurons at the ultrastructural level. Z. Zellforsch. 91, I-74 (1968).

Jacobson, M., Baker, R. E.: Neuronal specification of cutaneous nerves through connections with skin grafts in frog. Science 160, 543-545 (1968).

Jacobson, M., Baker, R. E.: Development of neuronal connections with skin grafts in frogs: Behavioral and electrophysiological studies. J. comp. Neurol. 137, 121-142 (1969).

Lyne, A. G., Hollis, D. E.: Merkel cells in sheep epidermis during fetal development. J. Ultrastruct. Res. 34, 464-472 (1971).

Mathan, M., Hermos, J. A., Trier, J.S.: Structural features of the epithelio-mesenchymal interface of rat duodenal mucosa during development. J. Cell Biol. 52, 577-588 (1972).

Merkel, F.: Über die Endigungen der sensiblen Nerven in der Haut der Wirbeltiere. Rostock: H. Schmidt 1880 .

Miner, N.: Integumental specification of sensory fibers in the development of cutaneous local sign. J. comp. Neurol. 105, 161-170 (1956).

Munger, B. L.: The intraepidemal innervation of the snout skin of the opossum. A light and electron microscope study, with observations on the nature of Merkels' Tastzellen. J. Cell Biol. 26, 79-97 (1965).

Nafstad, P. H. J.: Comparative ultrastructural study on Merkel cells and dermal basal cells in poultry (Gallus domesticus). Z. Zellforsch. 116, 342-348 (1971 a).

Nafstad, P. H. J.: On the ultrastructure of neuro-epithelial interactions. The dermal innervation in the snout of the pig. Z. Zellforsch. 122, 528-537 (1971 b).

Nafstad, P. H. J.: On the dermal innervation. Z. Anat. Entwickl.-Gesch. 135, 337-349 (1972).

Nafstad, P. H. J., Andersen, A. E.: Ultrastructural investigation on the innervation of the Herbst corpuscle. Z. Zellforsch. 103, 109-114 (1970).

Nakai, Y.: On different types of nerve endings in the frog median eminence after fixation with permanganate and glutaraldehyde-osmium. Z. Zellforsch. 119, 164-178 (1971).

Oppenheimer, D. R., Palmer, E., Weddell, G.: Nerve endings in the conjunctiva. J. Anat. (Lond.) 92, 324-353 (1958).

Overton, J.: The fate of desmosomes in trypsinized tissue. J. exp. Zool. 168, 203-214 (1968)

Taylor, A. C., Kollros, J. J.: Stages in the normal development of Rana pipiens larvae. Anat. Rec. 94, 7-23 (1946).

Toner, P. G., Ferguson, A.: Intraepithelial cells in the human intestinal mucosa. J. Ultrastruct. Res. 34, 329-344 (1971).

P. H. J. Nafstad

Department of Anatomy

The Veterinary College of Norway

Postboks 8146

Oslo 1, Oslo-Dep., Norway
R. E. Baker

Department of Zoology

The University of Michigan

Ann Arbor

Michigan 48104, USA 